\title{
Recovery of Iron Values from Waste Manganiferous Iron Ore Fines for Pellet Making
}

\author{
Shobhana Dey ${ }^{1}$, Manoj Kumar Mohanta ${ }^{1}$, Manik Chand Goswami' ${ }^{1}$, Santosh Pani ${ }^{2}$ \\ ${ }^{1}$ Mineral Processing Division, CSIR-National Metallurgical Laboratory (Council of Scientific and Industrial \\ Research), Jamshedpur, India \\ ${ }^{2}$ Centre for Minerals Research, Chemical Engineering Department, University of Cape Town, Cape Town, South \\ Africa \\ Email: sd@nmlindia.org
}

Received 15 April 2014; revised 6 June 2014; accepted 25 June 2014

Copyright (C) 2014 by authors and Scientific Research Publishing Inc.

This work is licensed under the Creative Commons Attribution International License (CC BY). http://creativecommons.org/licenses/by/4.0/

(c) (i) Open Access

\begin{abstract}
A large volume of overburden and mine wastes is generated during the extraction and beneficiation of the low grade ores. The waste low grade manganiferous iron ore fine from southern part of India was studied for recovery of iron values. The chemical assay of the sample is $52.36 \% \mathrm{Fe}$, 4.75\% $\mathrm{Mn}, 8.5 \% \mathrm{SiO}_{2}$ and $2.82 \% \mathrm{Al}_{2} \mathrm{O}_{3}$. The characterization study of the sample indicates the presence of microplaty hematite, goethite, pyrolusite, cryptomelane with minor amount of quartz and kaolinite. The beneficiation study of the sample does not respond to the conventional route of desliming the ground feed followed by gravity separation and magnetic separation. Therefore, an alternative technique of reduction roasting using a producer gas was attempted at different conditions. The characterization of roasted product reveals the phase transformation to magnetite and microplaty magnetite. The low intensity magnetic separation conducted with the roasted products generated at optimal condition shows that $70 \%$ concentrate having $64.5 \%$ Fe and $1.87 \%$ Mn could be produced. The high manganese in the concentrate works as an additive for making pellet with enhancement in pellet strength and drop in reducibility. Utilization of mines waste has significant impact on mineral resources and environmental hazard.
\end{abstract}

\section{Keywords}

Recovery of Resource, Mine Waste, Overburden, Manganiferous Iron Ore, Reduction Roasting

"Corresponding author.

How to cite this paper: Dey, S., Mohanta, M.K., Goswami, M.C. and Pani, S. (2014) Recovery of Iron Values from Waste Manganiferous Iron Ore Fines for Pellet Making. Journal of Minerals and Materials Characterization and Engineering, 2, 513-521. http://dx.doi.org/10.4236/immce.2014.25052 


\section{Introduction}

Million tons of useful minerals are discarded in terms of fines and slimes every year, which lead to a rise in mines waste an environmental impact [1]. It is estimated that the mining and processing of mineral ores generate about 1.8 billion tons of waste each year in the United States as well as in the world [2]. Mineral processing wastes account for nearly half of all the solid waste that is generated each year in the United States. Accumulations of mineral wastes from decades of past mining activities probably account for at least 55 billion tons of material [3]. In Indian scenario, a large volume of overburden and waste materials in the scale of 1.86 billion tons are generated (Figure 1) while excavating only 750 million tons of minerals [4]. This much of waste was generated only in one year i.e. 2005-2006. The total quantum of waste generated in seven years between 19002006 was 10,767 million tons. Amongst the main minerals, the iron ore mining occupies the third position in producing the waste through overburden and production. It is expected that the amount of overburden generated will increase along with the increase in mineral extraction.

Mining wastes are generated during the process of extraction and processing of minerals. Extraction is the first phase that consists of the initial removal of ore from the earth. This is normally done by the process of blasting, which results in generation of large volume of waste (soil, debris and other materials). This is worthless for the industry and is normally just stored in big piles within the mine lease area, and sometimes on public/forested land (Figure 2). Open-pit mines produce 8 to10 times as much waste as underground mines. As the higher grade mineral deposits are getting exhausted, the mineral industry is generating more waste. The quantity and composition of waste rock varies greatly from site to site, but these wastes essentially contain the minerals associated with both the ore and host rock.

The overburden in iron mines consists of weathered ore with clay particles and mainly lateritic layers along with low iron content. The characteristics of low grade fines and slimes vary from region to region, and different beneficiation strategies are required to process them [5]. Indian iron ore from Orissa, Jharkhand and Goa are hematitic ore with quartz-kaolinite association whereas those in western Dhrawar Craton and especially in Karnataka are hematite-magnetite in association with manganese minerals, quartz and kaolinite. As the manganese bearing bands are of relatively low strength, the crushing and sizing to above $10 \mathrm{~mm}$ leads to the removal of manganiferous minerals to $10 \mathrm{~mm}$ fraction which occurs as mines waste at present and creates an environmental impact. The beneficiation of the former is focused on upgrading the Fe in the concentrate by lowering of alumi-

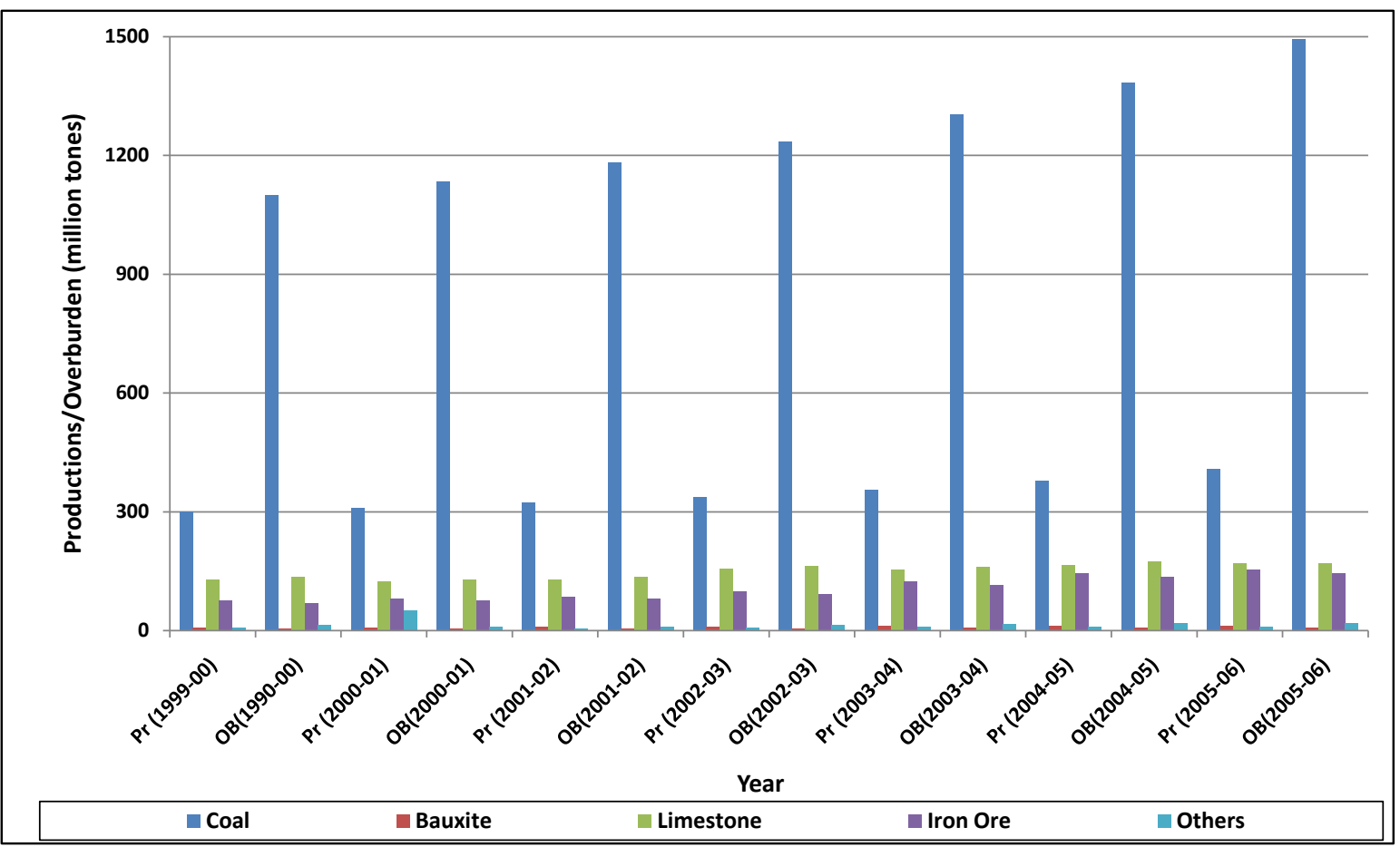

Figure 1. The Overburden mining wastes in different mines of India (Pr: Produced, OB: Overburden). 


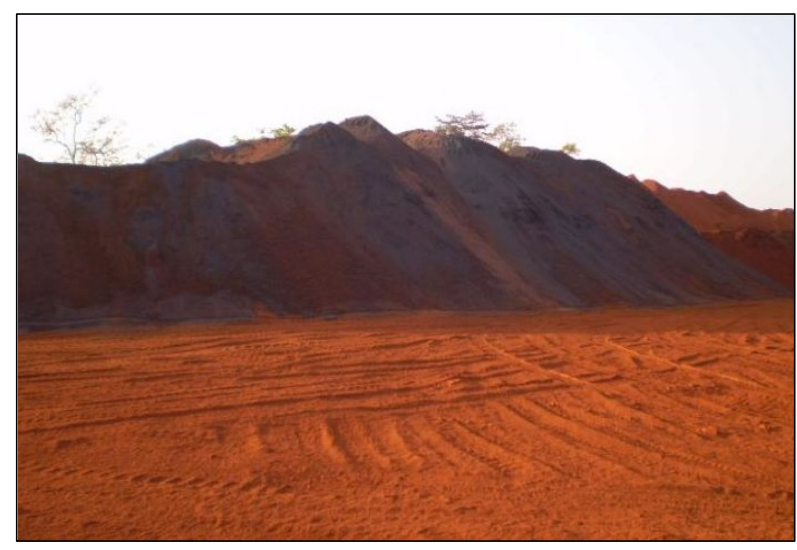

Figure 2. The overburden mining wastes in Iron ore Mine of India (Southern Part).

na and silica [6] [7] whereas the processing of latter is focused also on the lowering in Mn-content. The high manganese content in the iron ore fine is an attractive characteristic for the pellet feed. Manganese as a compound or ore added to magnetite and hematite concentrates enhances the pellet strength and decrease reducibility [8]. It was found that the manganese dioxide, carbonate and the ores are satisfactory additives. These additives increased the pellet compression strengths with a corresponding loss of reducibility, as compared to the pellets without manganese additions.

India is the fourth largest producer of iron ores in the world and occupies sixth position in world's iron ore reserves. About 167 million tons of iron ores constituting lumps, fines and concentrates were produced in the year 2011-2012, showing decrease of about 19\% as compared to that in the year 2010-2011 [9]. Indian iron ore should be able to sustain the projected domestic steel demand for over 200 years [10]. The current iron ore resources of about 25 billion tones will last for 75 to 85 years as steel production touches 400 million tons by 2020 . As the demand of iron ore is increasing, it is necessary to recover the resources from the mines wastes or leangrade iron ore through beneficiation. In that case the feed to sinter or pellet can be recovered. The present study explores to develop a strategy for beneficiation of the waste manganiferous iron ore fines for its suitable utilization in pellet making.

\section{Materials and Characterization}

\subsection{Materials}

The manganiferous iron ore sample received from Southern part of India was used in the investigation assaying $52.38 \% \mathrm{Fe}, 4.75 \% \mathrm{Mn}, 8.5 \% \mathrm{SiO}_{2}$ and $2.83 \% \mathrm{Al}_{2} \mathrm{O}_{3}$. The alumina content in the sample is not significant. The loss of ignition (LOI) of the sample is as high as $8.5 \%$ which indicates the presence of hydrated iron mineral. The particle size distribution in the as-received sample ranges from $10 \mathrm{~mm}$ to $32 \mu \mathrm{m}$. The $32 \mu \mathrm{m}$ size class is $20 \%$ and $+8 \mathrm{~mm}$ fraction is $4 \%$.

\subsection{Characterization}

The characterization of the sample indicates that the ore is lateritic in nature with ochreous brown color. The ore contains goethite, hematite and martite (Figure 3(a)) and minor amount of quartz, kaolinite, pyrolusite, psilomelane-creptomelane, hausmannite and magnetite. Presence of goethite interlocked with kaolinitic clay is responsible for high alumina. The manganese dioxide is contributed by the minor phases of pyrolusite, cryptomelane-psilomelane and hausmauite in the grains of finer size class (Figure 3(b), Figure 3(c) and Figure 3(d)). The XRD study also suggests that goethite is the dominating phase followed by hematite in the bulk sample (Figure 4). Quartz and pyrolusite are present in very low amount. As the presence of manganese bearing minerals is not significant, the peaks of majority manganiferous minerals do not appear in XRD. The Thermo gravimetric-Differential Thermal analysis (TG-DTA) of the sample shows an endothermic phase transition coupled with weight loss at $430^{\circ} \mathrm{C}$ indicating the dehydration of goethite. The ore starts softening at $940^{\circ} \mathrm{C}$ showing an exothermic reaction at $1340^{\circ} \mathrm{C}$. 


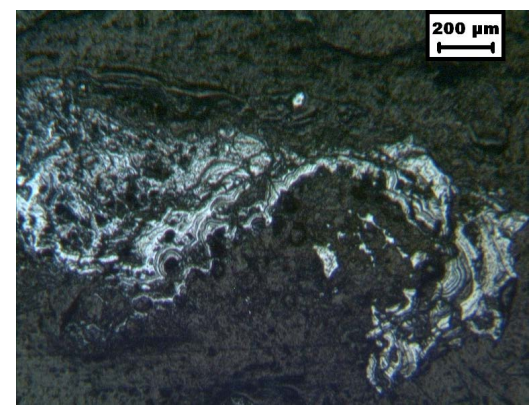

(a)

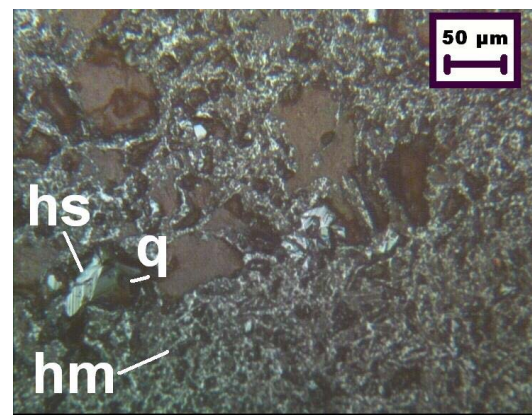

(c)

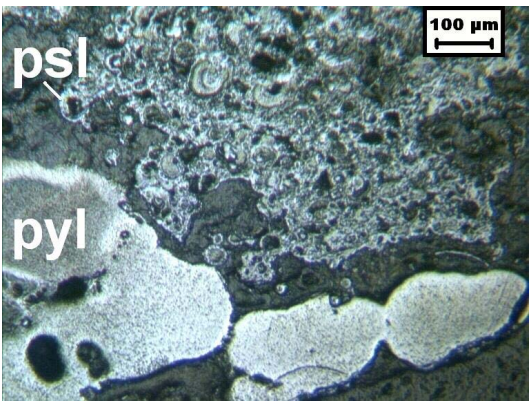

(b)

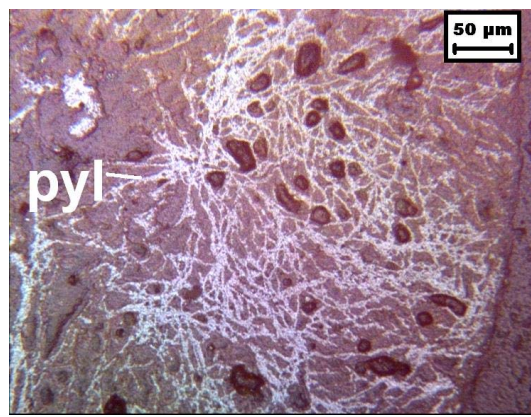

(d)

Figure 3. Microphotographs of manganiferous iron ore waste fines. (a): Psilomelane; (b): Pyrolusite and psilomelane associated with gangue; (c): Hematite, hausmannite and quartz; (d): Pyrolusite tubes within gangue.

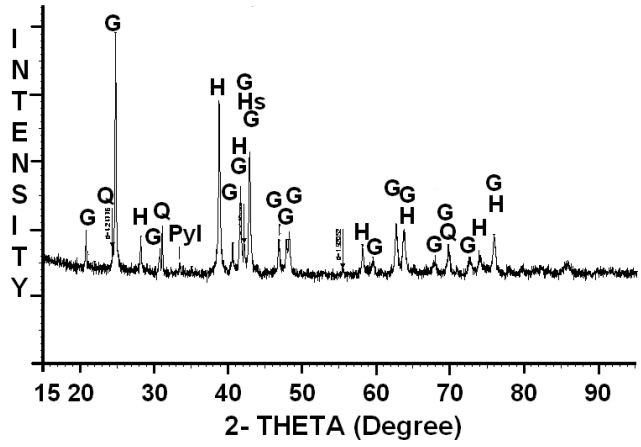

Figure 4. XRD of the feed sample. Goethite (G), hematite (H), and magnetite $(\mathrm{M})$ are the major phases. Quartz $(\mathrm{Q})$ and pyrolusite $(\mathrm{P})$ are the minor phases.

\section{Methods}

The main endeavor of the beneficiation is to produce a concentrate that can be used as pellet feed after blending with a concentrate having a low manganese and high Fe. Initially the top size of the material was crushed down to $1 \mathrm{~mm}$ in a closed circuit. The particle size distribution in $-1 \mathrm{~mm}$ sample and the chemistry are given in Figure 5. It reveals that the $-1+0.15 \mathrm{~mm}$ fraction is about $70 \%$ by weight with $52 \% \mathrm{Fe}$ and $5 \% \mathrm{Mn}$. The distribution of $\mathrm{Fe}$ and $\mathrm{Mn}$ in this fraction is about $74 \%$ and $81 \%$ respectively. The Fe content in each size fraction is uniformly distributed over $32 \mu \mathrm{m}$. The size class of $-32 \mu \mathrm{m}$ assaying $49.4 \% \mathrm{Fe}, 14.7 \%$ silica and $3.65 \%$ alumina is rich with gangue components. The desliming of $-1 \mathrm{~mm}$ ore was carried out using a 2" Mozley hydrocyclone at $20 \mu \mathrm{m}$ cut point for effective separation. The hydrocyclone underflow was subjected to spiral concentrator to produce a pre-concentrate for the downstream processing. The mineralogical complexity observed from the characterization studies suggested that the reduction roasting could be effective to improve the iron content in the concentrate. The approach was made to carry out the reduction roasting using a sample directly crushed to different feed sizes and also the pre-concentrate spiral product for improving the yield and grade. The reduction 


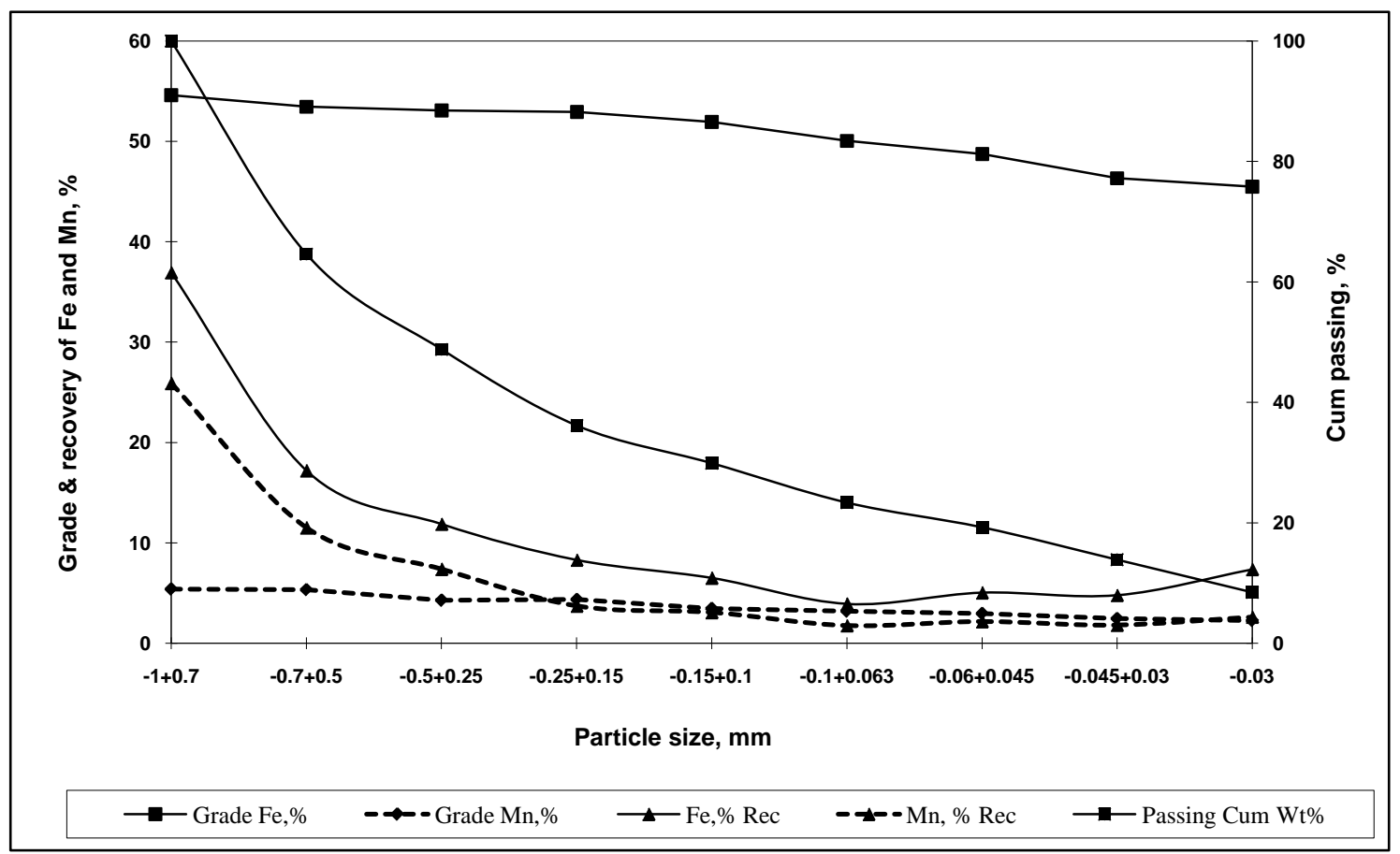

Figure 5. Distribution of particles and their chemistry in crushed to $1 \mathrm{~mm}$.

roasting was carried out in tubular furnace using producer gas (mixture of $\mathrm{CO}$ and $\mathrm{N}_{2}$ in the proportion of 30:70 ratio) at a flow rate of $4-5 \mathrm{~L} / \mathrm{min}$ and at two different temperatures, viz. $570^{\circ} \mathrm{C}$ and $650^{\circ} \mathrm{C}$. The loss in weight after heating was recorded. The roasted sample was ground to finer size for conducting the magnetic separation at low intensity magnetic field (500 Gauss). The results obtained with different feed types are compared.

\section{Results and Discussion}

The hydrocycloning of the feed increases the efficiency of any separation process as it narrows down the sizeclass of the feed before subjected to gravity separation. The slurry density was kept at $10 \%$. The spigot opening of $6.2 \mathrm{~mm}$ and feed pressure of $12 \mathrm{psi}$ were applied for fine cut of the particles. This operation removes the ultrafine assaying $40.87 \% \mathrm{Fe}$ and improves the Fe grade in the underflow from $52.4 \%$ to $54.74 \%$ at a yield of $85.6 \%$ (Table 1). The recovery of Fe in underflow is about $88.8 \%$ and that in the overflow is only $11.2 \%$. The cut size in the hydrocyclone overflow is around $20 \mu \mathrm{m}$ and used as reject. The hydrocyclone underflow was subjected to spiral concentrator. The results are discussed in next subsection.

\subsection{Gravity Separation by Spiral Concentrator}

Gravity concentration is the preferred route for separating the non-magnetic or low sp.gr. minerals like quartz or kaolinitic clay from heavy minerals in view of the greater economic viability. The hydrocyclone underflow being an improved feed was used for the spiral concentration. The yield of the spiral concentrate is $56 \%$ with an assay of $57.4 \% \mathrm{Fe}$; however the reduction of Mn distribution in the concentrate is not significant (Figure 6). The specific gravity of the iron and manganese bearing minerals is very close which inhibits the effective gravity separation. The enrichment of the iron content is also not significant due to the interlocking of the gangue minerals. The yield of spiral tailing is $29.6 \%$ having a significant amount of Fe (50\%). This loss is due to inadequate liberation of the feed material at $-1 \mathrm{~mm}$ particle size.

The presence of ochreous goethite indicated by the characterization of sample implies the difficulty to produce a concentrate with $65 \%$ Fe even at very fine size. Therefore, reduction roasting route was conducted separately with sample directly crushed to different sizes and the spiral concentrate. The reduction roasting converts the goethite and hematite to magnetite which can be separated from the silicate and clayey gangues by low intensity magnetic separation [11]. 
Table 1. Hydrocycloning results of $-1 \mathrm{~mm}$ feed.

\begin{tabular}{cccc}
\hline Products & Wt \% & Fe \% & Mn \% \\
\hline Hydrocyclone Underflow & 85.6 & 54.74 & 4.68 \\
Hydrocyclone Overflow & 14.4 & 40.87 & 5.04 \\
Hydrocyclone Feed & 100.0 & 52.61 & 4.73 \\
\hline
\end{tabular}

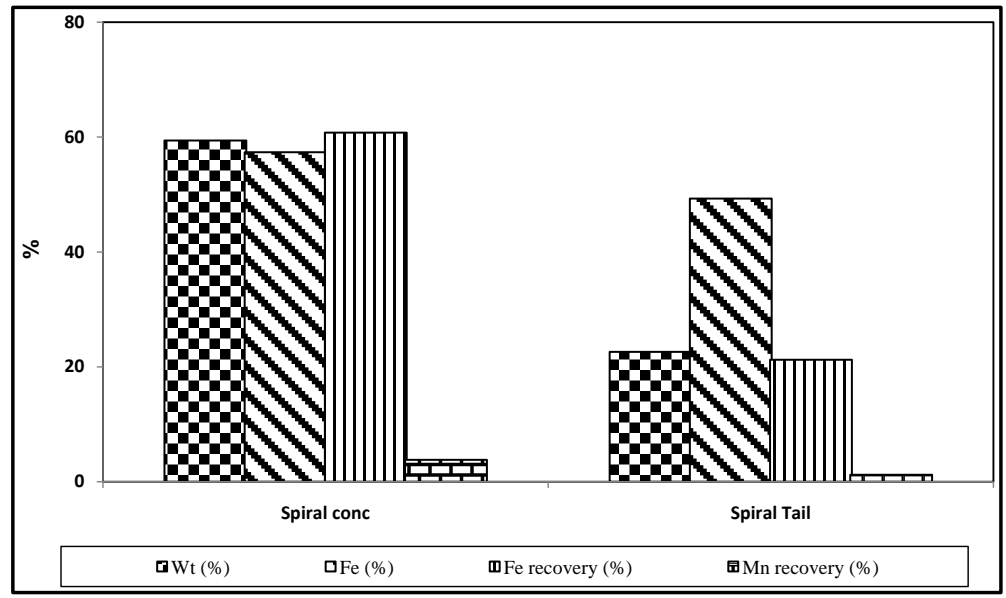

Figure 6. Spiralling of hydrocyclone underflow.

\subsection{Reduction Roasting}

The heat treatment study was attempted in view of improving the grade and recovery of the concentrate. Some of the researchers had used reduction roasting for characterizing the goethitic iron ore [12] [13]. Initially the reduction roasting was carried out with $-1 \mathrm{~mm}$ crushed sample at two different temperatures, viz. $570^{\circ} \mathrm{C}$ and $650^{\circ} \mathrm{C}$ for different exposure time. Under this condition, the goethite and hematite undergo phase transformation. The magnetizing reduction roasting with producer gas under the heat treatment converts the iron oxide/hydroxide mineral into hematite or magnetite, facilitating magnetic separation at low intensity, separating out the nonmagnetic manganese. The results of reduction roasting at $570^{\circ} \mathrm{C}$ and $650^{\circ} \mathrm{C}$ are presented in Figure 7. The iron grade in the roasted sample at both the conditions is very similar; however, the yield of the roasted product and Fe recovery is higher at $570^{\circ} \mathrm{C}$. The yield is about $89 \%$ with $57.8 \%$ Fe which most likely due to the phase transformation of goethite to magnetite. The phase transformations in the roasted samples characterized by the microscopic studies are discussed in the next section. The increased reduction roasting time from 30 minutes to 60 minutes at $570^{\circ} \mathrm{C}$ did not show any significant improvement in the Fe grade of the roasted sample (Figure 8).

The magnetic separation of the roasted sample ground to $150 \mu \mathrm{m}$ was carried out at low magnetic field (500 Gauss). The magnetization of the feed sample facilitates the magnetic separation at low intensity separating out the manganese and other gangues in the non-magnetic fraction. The recovered magnetics at $570^{\circ} \mathrm{C}$ is found to be more than that at $650^{\circ} \mathrm{C}$. The stability diagram [14] of different iron oxides signifies that temperature higher than $570^{\circ} \mathrm{C}$, hematite $\left(\mathrm{Fe}_{2} \mathrm{O}_{3}\right)$ is first transformed into magnetite $\left(\mathrm{Fe}_{3} \mathrm{O}_{4}\right)$, then into wustite $\left(\mathrm{Fe}_{1-y} \mathrm{O}\right)$. Wustite has less magnetic susceptibility than hematite or magnetite as its degree of magnetization depends on its stoichiometric ratio. The low temperature reduction roasting is always preferable as it makes the process more energy efficient. The concentrate recovered after magnetic separation of roasted sample at $570{ }^{\circ} \mathrm{C}$ is $70 \%$ with $64.5 \%$ Fe which is $8 \%$ more than at $650^{\circ} \mathrm{C}$. The Mn-content in the concentrate reduces to $1.87 \%$ (Figure 9). This is believed to be one of the ways to improve the grade of Fe from $52 \%$ to $64.5 \%$ with $70 \%$ yield. In view of the results on $-1 \mathrm{~mm}$ feed, attempts have also been made with the coarser feed of $-3 \mathrm{~mm}$ and $-5 \mathrm{~mm}$ at $570^{\circ} \mathrm{C}$ for different exposure time (Figure 8).

The magnetic concentrates recovered from the ground roasted products of $-3 \mathrm{~mm}$ and $-5 \mathrm{~mm}$ at low magnetic field intensity and their chemical assay are shown in Figure 9. It seems that for $-5 \mathrm{~mm}$ feed, even at a longer residence time of reduction roasting, the Fe grade in the concentrate is much less than at $-1 \mathrm{~mm}$ and $-3 \mathrm{~mm}$. It also appears that the yield of concentrate is maximum at 60 second of reduction roasting for $-1 \mathrm{~mm}$ and $-3 \mathrm{~mm}$ is maximized. Further increase in time reduces the yield drastically and that may be due to the formation of wus- 


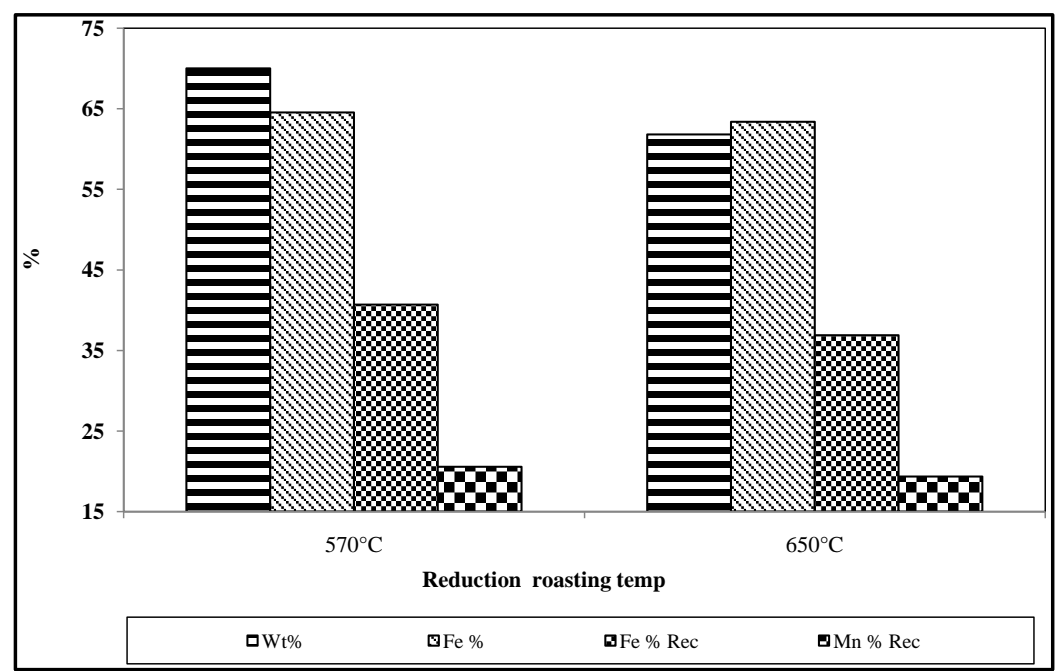

Figure 7. Reduction roasting of $-1 \mathrm{~mm}$ sample at two different temperatures.

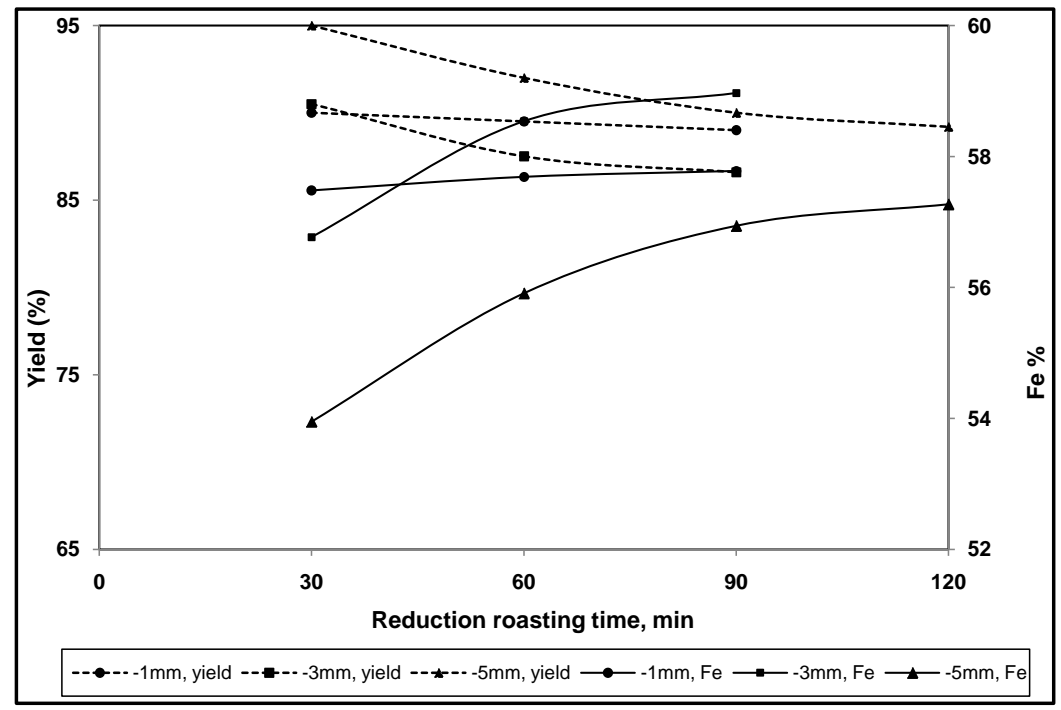

Figure 8. Comparison of reduction roasting products with different feed size at $570^{\circ} \mathrm{C}$.

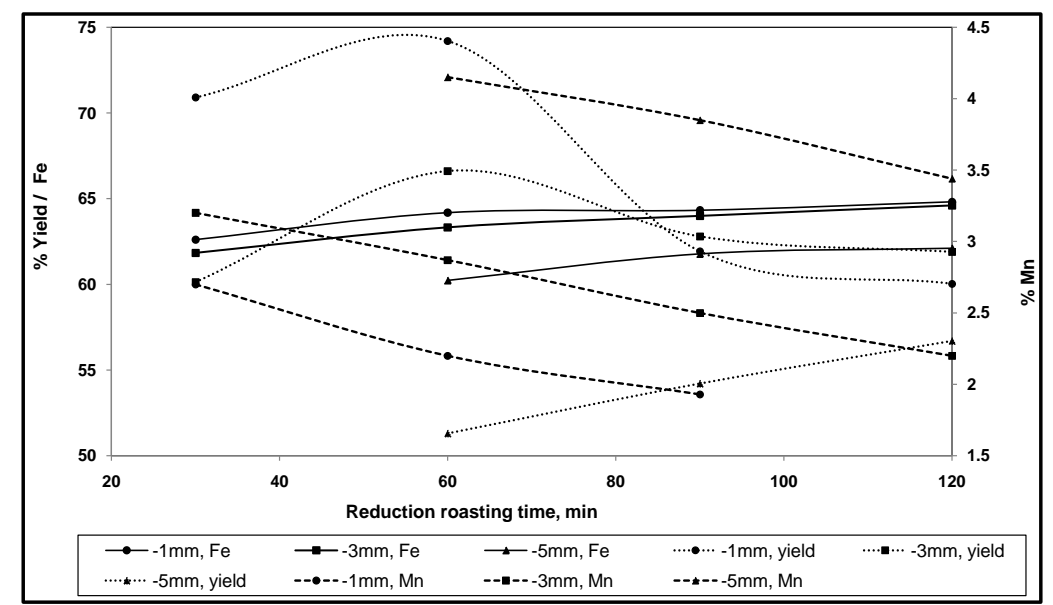

Figure 9. Magnetic separation of the reduction roasting substances. 
tite phase which is less susceptible at low magnetic field. The manganese content in the concentrate reduces with finer feed size and increasing the exposure time. The finer size having an adequate liberation causes to produce a concentrate with high Fe and less Mn. The blending of this concentrate with hematitic iron ore containing $0.1 \% \mathrm{Mn}$ in $65: 35$ ratio lowers the $\mathrm{Mn}$ concentrate to $1.25 \%$ level. That can give enough strength to the pellets.

\subsection{Characterization of Roasted Sample}

The microscopic study of waste manganiferous iron ore fines subjected to reduction roasting are shown in Figure 10. There is absence of goethite in the product. In the bulk sample, the grains get segregated due to the phase transformation to magnetite. Reflectance microscopy shows the thermal effect on both Fe-minerals and Mn-minerals. In case of coarser size, the larger grains have escaped reduction at the core. The roasted product under polarizing microscope exhibits magnetite and microplaty magnetite (Figure 10(a), Figure 10(b) \& Figure 10(d)) derived from their hematitic precursor. Microplaty hematite and small sized martite grains (20 - 50 $\mu \mathrm{m}$ size) have completely transformed to magnetite. In some cases (coarser size) the incomplete reduction has resulted in a magetitic rim with hematitic core as the grain boundary had direct exposure to the gas. However, the grains of latter type will also attain enhanced magnetic susceptibility which may play a critical role in the magnetic separation.

\subsection{Reduction Roasting with Spiral Concentrate}

The spiral concentrate generated from $-1 \mathrm{~mm}$ feed was subjected to reduction roasting under similar condition, i.e. at $570^{\circ} \mathrm{C}$ for 60 second followed by magnetic separation of the ground $(-150 \mu \mathrm{m})$ roasted product. The results obtained from two different feed types are given in Table 2. There is an improvement in the Fe grade $(65.5 \% \mathrm{Fe})$ with spiral concentrate and the Mn-content reduces to $1.6 \%$; however, the yield is not encouraging. The overall concentrate yield is only $37 \%$. This indicates that due to the less propensity of the gravity separation

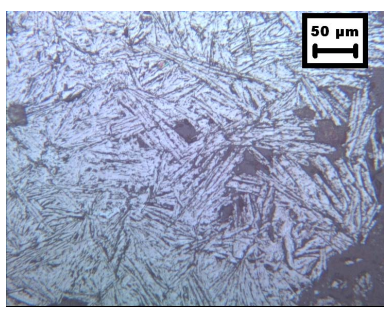

(a)

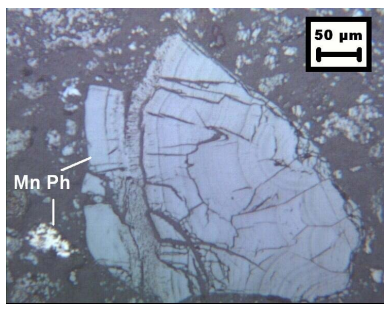

(c)

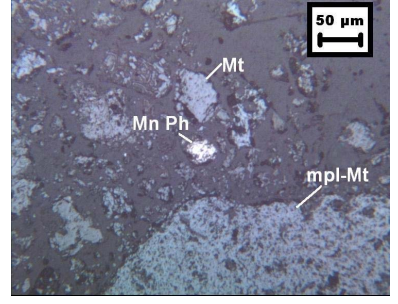

(b)

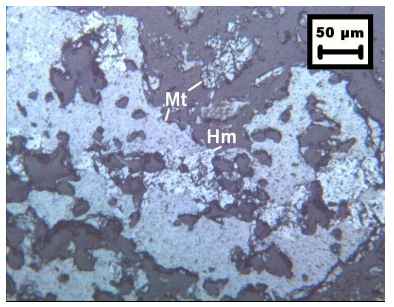

(d)

Figure 10. Characterization of reduction roasted product. (a): Microplaty magnetite; (b): Mn-phases and microplaty magnetite; (c): Manganiferous phase (pyrolusite) with colloform/botryodial features; (d): Microplaty magnetite and relict hematite.

Table 2. Magnetic concentrate from reduction roasting of different types of feed.

\begin{tabular}{cccc}
\hline Feed & Wt \% (With Respect to Original) & Fe \% & Mn \% \\
\hline Direct Feed of $-1 \mathrm{~mm}$ & 70.0 & 64.5 & 1.87 \\
Direct Feed of $-3 \mathrm{~mm}$ & 61.9 & 63.9 & 2.18 \\
Spiral concentrate & 37.0 & 65.5 & 1.6 \\
\hline
\end{tabular}


the overall yield of the magnetic concentrate from the roasted product significantly reduces.

\section{Conclusions}

The waste manganiferous iron ore fine sample was investigated in the present study for recovering of the iron values for suitable utilization in pellet feed. The salient points are drawn from the above studies:

- The mineralogical studies indicate that the sample dominantly consists of goethite, hematite and martite with minor amount of pyrolusite, psilomelane, hausmauite quartz and kaolinite. Goethite in the ore gives it an ochreous appearance.

- The liberation studies indicated that distribution of manganese is almost uniform even at fine size. It is difficult to enhance the iron content above $62 \%$ by a conventional route.

- The phase transformation occurs from goethite to hematite or magnetite during reduction roasting of the sample which facilitates the up-gradation of Fe in the concentrate to $65 \%$.

- Reduction roasting process shows encouraging results with both the feed sizes ( $-3 \mathrm{~mm}$ and $-1 \mathrm{~mm}$ ), however, the recovery is substantially high with $-1 \mathrm{~mm}$ feed. It might be possible to improve the recovery of the concentrate to $70 \%$ with $64.5 \%$ Fe and $1.87 \%$ manganese in the concentrate.

- The processing of mines waste is a possible option to conserve the mineral resources and protect the environment.

\section{References}

[1] Pradip, P. (2006) Processing of Alumina-Rich Indian Iron Ore Slimes. International Journal of Minerals, Metals and Materials Engineering, 59, 551-555.

[2] Collins, R.J. and Ciesielski, S.K. (1994) Recycling and Use of Waste Materials and By-Products in Highway Construction National Cooperative Highway Research Program Synthesis of Highway Practice 199. Transportation Research Board, Washington DC.

[3] U.S. Environmental Protection Agency (1985) Report to Congress on Wastes from the Extraction and Beneficiation of Metallic Ores, Phosphate Rock, Asbestos, Overburden from Uranium Mining, and Oil Shale. Report No. EPA/530SW-85-033, Washington, DC.

[4] Mine Waste Management Report (2009) http://miningandblasting.files.wordpress.com/2009/09/mine-wastes-management.pdf

[5] Mishra, B.K., Reddy, P.S.R., Das, B., Biswal, S. and, Prakash, S. (2007) Issues Relating to Characterization and Beneficiation of Low Grade Iron Ore Fines. Steelworld, Mumbai, 34.

[6] Pani, S., Dey, S., Mohanta, M.K. and Singh, R. (2010) An Approach for Recovery of Iron Values from Slimes. Proceedings of the XI International Seminar on Mineral Processing Technology (MPT-2010). Jamshedpur, December 2010, 612-620.

[7] Dey, S., Pani, S., Mohanta, M.K. and Singh, R. (2012) Utilization of Iron Ore Slimes: A Future Prospective. Separation Science and Technology, 47, 769-776. http://dx.doi.org/10.1080/01496395.2011.621501

[8] Schluter, R.B. (1974) Influence of Manganese Additions upon Properties of Iron Ore Pellets. Bureau of Mines Report of Investigations, RI 7870.

[9] Minerals Year Book (Part III Minerals Review) (2012) 5th Edition, Indian Bureau of Mines, Nagpur, Chapter 28, Page 2.

[10] Federation of Indian Mineral Industry (FIMI) Report (2008) Creating a Vibrant Iron Ore Industry in India-A Survey. $1-2$.

[11] Connor, F.O., Cheung, W.H. and Valix, M. (2006) Reduction Roasting of Limonite Ores: Effect of Dehydroxylation. International Journal of Mineral Processing, 80, 88-99.

[12] Bleifuss, R.L. and Tufford, G.L. (1968) The System Fe-Mn- $\mathrm{SiO}_{2}-\mathrm{O}_{2}$ and Its Application to the Beneficiation of Manganiferous Iron Ores by Reduction Roasting. Society of Mining Engineers, 204-221.

[13] Fuller, H.C. (1994) Decomposition of Manganese Sulfate by a Partial Reduction Process. United States Bureau of Mines Reports, RI-6794.

[14] Bogdandy, L.I. and Engll, H.J. (1971) The Reduction of Iron Ores. Scientific Basis and Technology, 16-17. 
Scientific Research Publishing (SCIRP) is one of the largest Open Access journal publishers. It is currently publishing more than 200 open access, online, peer-reviewed journals covering a wide range of academic disciplines. SCIRP serves the worldwide academic communities and contributes to the progress and application of science with its publication.

Other selected journals from SCIRP are listed as below. Submit your manuscript to us via either submit@scirp.org or Online Submission Portal.
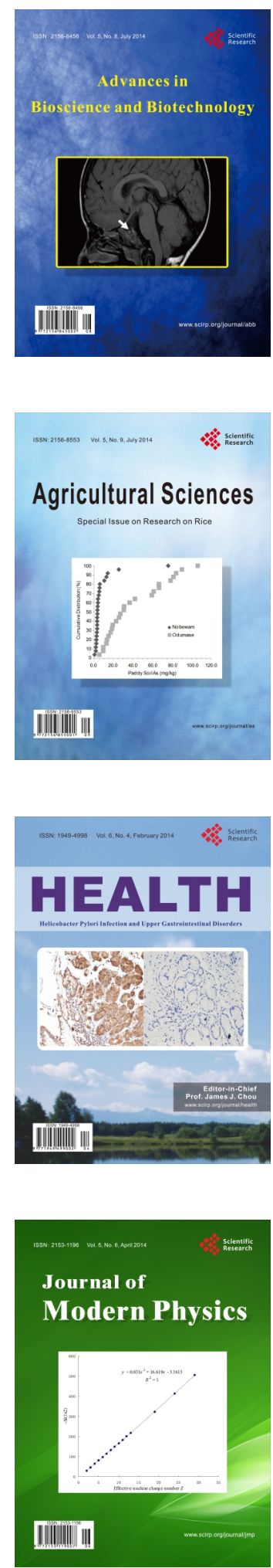
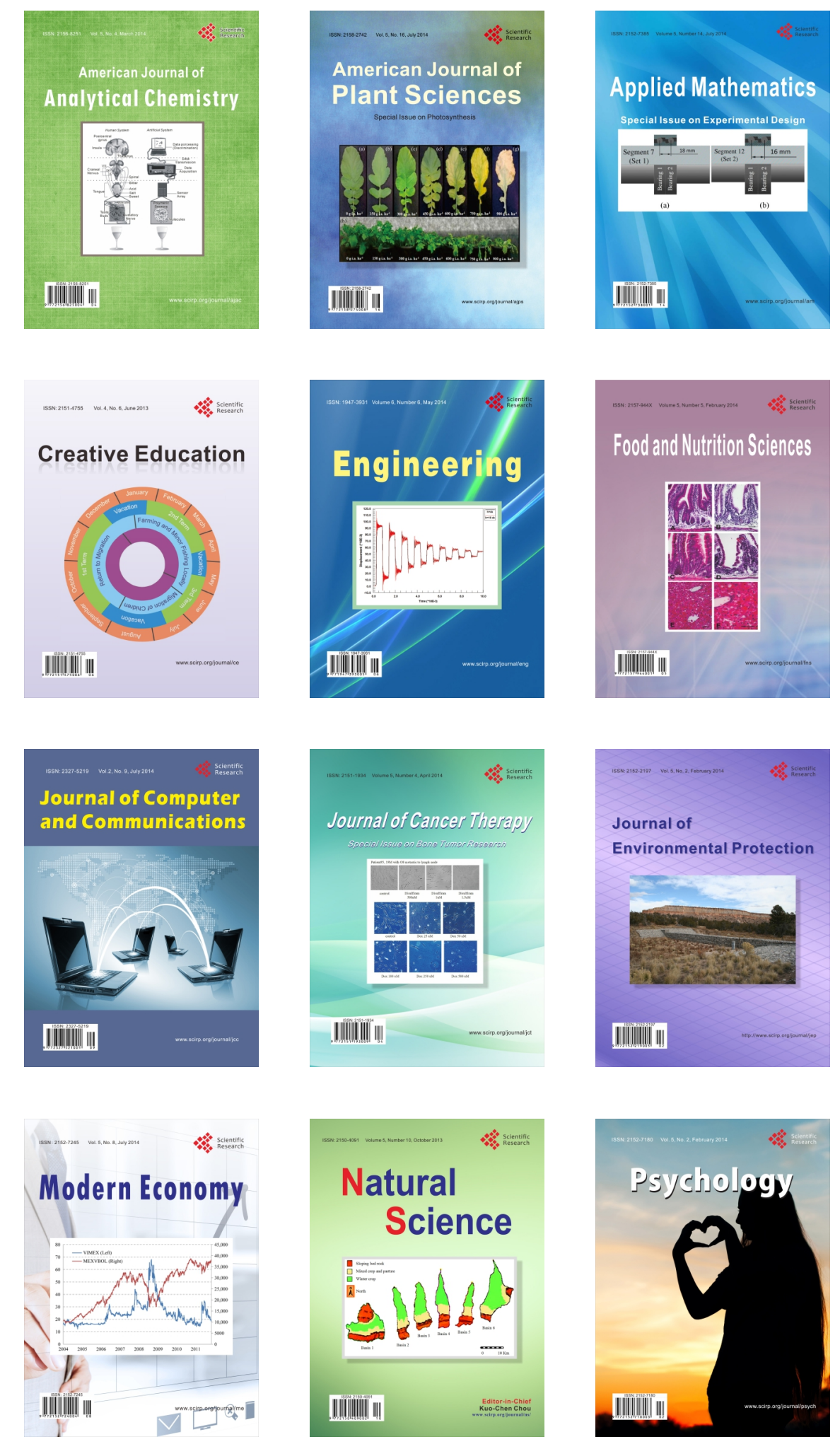